Tunitska Yuliia

$\mathrm{PhD}$ in Economics, Senior Lecturer, Department of International Economic Relations, Kyiv National University of Trade and Economics

Kyiv, Ukraine

ORCID 0000-0002-8501-1299

ResearcherID 9C-2968-2016

\title{
CLASSIFICATION OF INTERMEDIARIES IN FOREIGN ECONOMIC ACTIVITIES
}

Based on a study of the theoretical aspects of the activities of intermediaries in the domestic and foreign markets, this article maximally covers and systematizes the criteria for their classification in the context of participation in foreign economic activity, including on the Internet. The proposed classification criteria are as follows: "by discrete types of core and auxiliary activities» of the enterprise in accordance with the value chain of M. Porter and «by foreign trade activity type «.

Keywords: foreign trade, intermediaries, market agents, brokers, value chain.

\section{Туніцька Юлія. Класифікація посередників у зовнішньоекономічній діяльності.}

На основі дослідження теоретичних аспектів діяльності посередників на внутрішньому та зовнішніх ринках максимально охоплено та систематизовано критерії їх класифікачії у контексті участі в зовнішньоекономічній діяльності, в тому числі в мережі Інтернет. Запропоновано критерії класифікації «за дискретними видами основної та допоміжної діяльності» підприємства відповідно до ланцюжска створення вартості М. Портера та «за видами зовнішньоекономічної діяльності».

Ключові слова: зовнішньоекономічна діяльність, посередники, агенти, брокери, ланцюжок створення цінності.

Relevance of research topic. In the context of globalization and internationalization of the world economy, foreign economic mediation is of particular interest, playing an extremely important role in ensuring the effective foreign economic activity of domestic enterprises, faced with problems of selling goods and services in foreign markets and the necessity to reduce costs. Using intermediaries saves resources, accelerate business transactions, including export and import, and facilitates product quality.

Formulation of the problem. Nowadays, mediation concerns all aspects of foreign economic activity. Moreover, under conditions of development of e-commerce 
occurs a rapid internetization of this economic institute, which is a fact, requiring extensive research in this area. Therefore, a comprehensive approach to defining the criteria for the classification of intermediaries operating in the external economic field, understanding their functions and taking into account the current world development trends will increase the competitiveness of domestic enterprises in international markets.

Analysis of recent researches and publications. Studies of such domestic and foreign scientists are devoted to the study of problems of mediation in foreign economic activity: N.I. Duchynska [3], A.R. Dunska [4], O.O. Dyma [5-6], O.V. Dzyad [7], O.M. Kibik [13], T.S. Ruban [18-20], V.P. Samoylovska [21], V.A. Svichkar [24], K.Yu. Velychko [26] as well as works of the other scholars who analyzed the nature and types of mediation, economic consequences and conditions of their operation, as well as various aspects of such a complex market phenomena as intermediary in the field of foreign trade.

The article aims to develop an integrated system of classification criteria for intermediaries in foreign trade, which embraces existing approaches to the greatest extent possible and takes into account current trends of mediation internetization and its improvement by justifying new criteria.

Presenting main material. The International Chamber of Commerce (ICC) states in its Guidelines on the handling of agents, intermediaries and other third parties, that intermediaries are an effective tool for building, expanding and conducting international business. Even large companies in today's global world turn to third parties to cover all desired areas and market niches [9].

The analysis of scientific papers devoted to the study of mediators found out lots of approaches to their classification. In particular, the main classification features are the type of intermediary service, the sphere of activity [16, 20], type of indirect resources, [5], the nature of interaction with the principal [15], etc.

According to the Guidelines of the International Chamber of Commerce (ICC) on Agents, Intermediaries and Other Third Parties are allocated: legal and natural persons acting on behalf of the parent enterprise, (including agents, consultants, sales representatives, customs agents, subcontractors, franchisees, lawyers, accountants, other intermediaries); wholesale and retail merchants, carriers, internet service providers.

In accordance with the rules of the ICC intellectual property are allocated supply chain intermediaries, carriers, and online platforms [11].

According to the ICC Action Program for 2017-2018 are allocated: physical (suppliers of raw materials and accessories, carriers, proprietors who own premises, production facilities, and other fixed assets), online resellers (sites, platforms and portals) [12].

To combat counterfeiting ICC distinguishes companies that provide online infrastructure, search and payment services, ISPs, and online advertising agencies [10].

However, in the context of foreign economic activity in most of the works of domestic and foreign scientists limit the classification of intermediaries only by their 
role in foreign trade operations, divided by place in the market, depending on the scope of authority, etc.

When substantiating the classification of intermediaries in foreign economic activity, in our opinion, it is necessary to take into account the principles of systematicity and complexity, as well as the current trend of Internet mediation. The main thesis is that all types of foreign economic activity of an enterprise may require the involvement of an intermediary; intermediaries serve the FEA (foreign economic activity) entity at all stages of the value chain, for the most part, being themselves the subjects of FEA.

Analysis of theoretical achievements in this area allows covering the classification criteria of intermediaries in foreign trade to the most extent. Based on a presence on the Internet it is suggested to allocate online intermediaries (operating only on the web - sites, platforms, and portals), mixed (usually have their pages on the network and implement some features), and physical intermediaries (operating offline). Online intermediaries are divided by size, level of government regulation, level of commercialization, degree of obligation, level of independence, industry affiliation, visibility of the result, by type and scope of services provided. Mixed and physical intermediaries are classified by the systematic character of collaboration, customer specificity, territoriality, type of impact on the goods, display of work, degree of influence on the product, exclusivity.

We offer the criterion of classification of intermediaries in foreign economic activity «by discrete types of the main and auxiliary activity of the enterprise» based on the theory of the value-chain formation of M. Porter (Figure 1).

The intermediaries by the main activities include the following:

- Intra-logistic intermediaries (purchase and storage of materials and resources required for the production of goods),

- Production intermediaries (warehousing, transportation, pre-packing, packaging),

- External logistic intermediaries (storage and promotion of finished products on the market by certain types of transport in certain regions),

- Intermediaries in marketing (marketing) and sales (foreign trade). Marketing intermediaries help to properly assess the needs of the market and properly allocate resources, focus them toward the most popular products, increase the intangible component of goods utility (research companies), consulting and creative agencies, design bureaus, branding agencies, media agencies, sales houses, content production studios (Universal, Disney, etc.), License branding agencies, BTL-agencies, digital agencies, merchandising agencies, etc.).

Foreign trade intermediaries: intermediary organizations and specialized intermediaries. Intermediary organizations include:

- international general purpose type companies that accumulate products of a large number of manufacturers in different industries and supply them to wholesale or retail businesses or end consumers; 
- specialized companies are engaged in international trade and sell one certain type of products (eg food products) organizing its highly profitable sales and have a high level of competence and professionalism in the field of export-import of goods of the respective industries;

- international trading companies - affiliates of manufacturers are engaged in the sale of highly competitive high-tech goods (electrical engineering, communications, cars, etc.) and require direct contact with the consumer to organize after-sales service, create a prestigious brand image.

It is customary to classify specialized wholesale foreign trade intermediaries according to their place in the market, depending on the scope of authority.

- After-sales intermediaries (after-sales service). Intermediaries in the ancillary activities of the enterprise include:

- Intermediaries related to the creation and maintenance of the enterprise infrastructure (financial, information and legal). Financial intermediaries (banks, insurance companies, investment funds) provide financing for the enterprise (provide loans, leasing, etc.), insure risks, reduce accounts receivables (factoring, forfeiting), serve payments including international payments (collection, bills, etc.). Legal settlement mediators ensure consistency between business entities and the law of a certain countryб assist in resolving disputes between business process participants (law firms and consultants, etc.). Information brokers include research companies and consultants, information offices, databases. At the same time, they may apply to other types of intermediaries, such as marketing, etc. Human resources management intermediaries (state and non-state employment agencies). An entity that provides employment mediation services is a registered as prescribed by law legal entity, conducting business activities, regardless type of ownership, activity or management, as well as an individual entrepreneur providing employment placement services in Ukraine and/or abroad [27]. Employment intermediaries perform the following functions: job search and employment assistance; selection of employees in accordance with the orders of employers (particularly, foreign) within the framework of contracts concluded with employers. Private employment agencies in Ukraine can cooperate with territorial executive bodies implementing state policies in the field of employment and labor migration. Employment services for migrant workers are mainly provided by private employment agencies, and, in the domestic market, the intermediary functions are performed by the State Employment Services of Ukraine [7].

- Logistics intermediaries (necessary materials, raw materials, and resources) are various business entities, depending on the specialization of the company using such services (e.g. engineering companies, IT companies, etc.).

- R\&D, technology and engineering intermediaries are innovative intermediaries (they do not directly participate in the creation of innovations, but optimize the directions and volumes of financial, information, logistical and human resources to commercialize scientific and technological development and technology transfer). They serve as a liaison between all market participants, both from the 
demand and supply side of innovative products market and facilitate their progress at all stages of the innovation lifecycle, contribute to reducing the risk of venture investments by targeting consumers and establishing information, financial, staffing and logistical flows. Innovative intermediaries perform all the functions of innovative management, which allows inventors to concentrate their efforts on scientific activities, delegating specialists the work on promoting their developments [1].

In the EU, the activities of higher education institutions (universities) and research institutes use the most effective forms of organizing innovative companies, such as spinout and spin-off companies [2].

The list of principal and related ancillary activities may be adjusted (reduced) according to the industry specificity of the entity. Besides, in our opinion, it is quite possible to fully transfer the functions concerning ancillary activities to intermediaries.

Intermediaries are not only able to complement the value creation process, but also to integrate the resources of network members, coordinate their efforts, resulting in additional value for products. In our opinion, intermediaries should also be classified according to the types of FEA specified in the Law of Ukraine «On Foreign Economic Activity» (See Table 1).

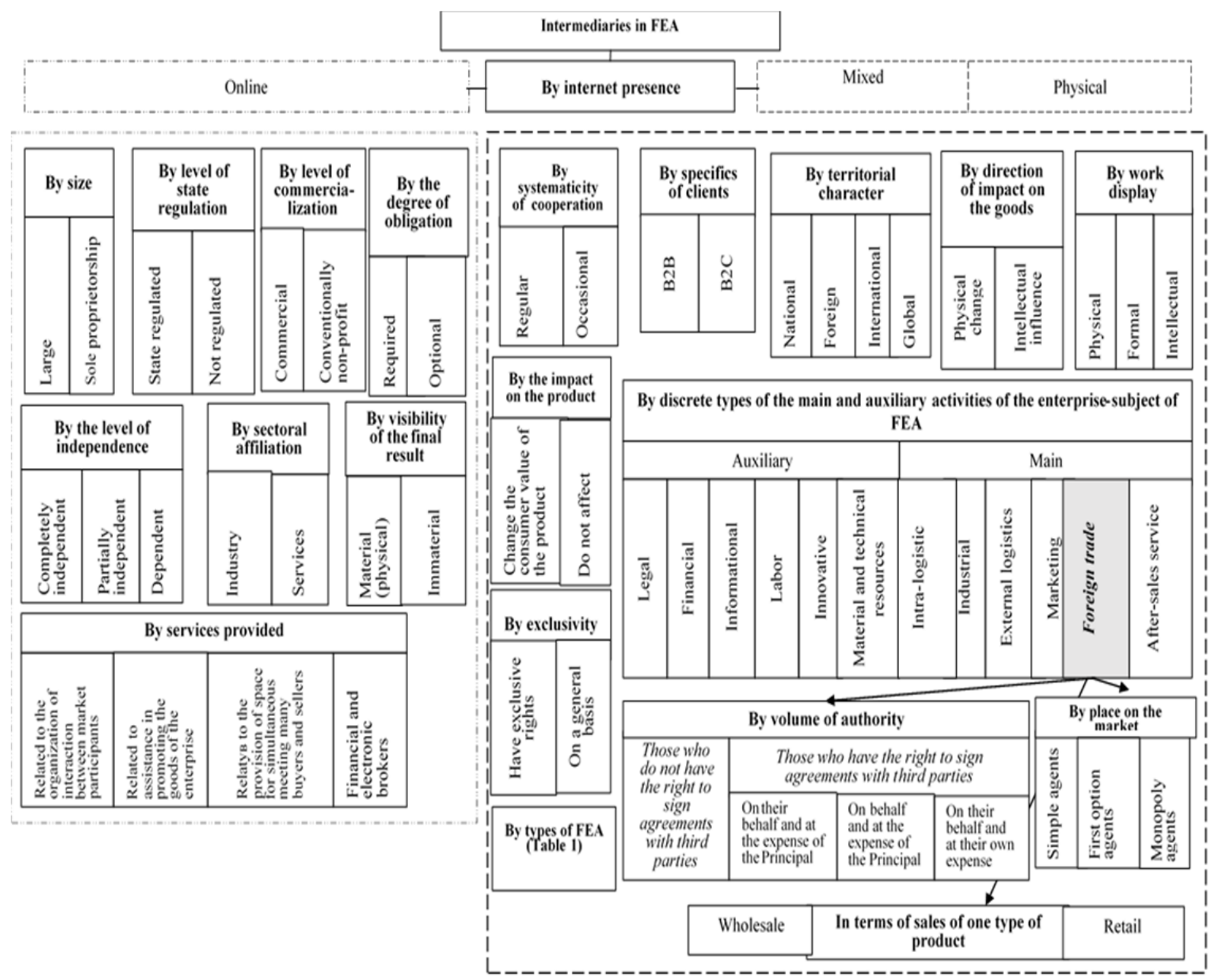

Figure 1. Classification of intermediaries in the field of foreign economic activity (FEA) of the enterprise 


\section{Intermediaries according to the types of FEA, conducted by an Enterprise}

\begin{tabular}{|c|c|}
\hline Types of FEA & Intermediaries \\
\hline $\begin{array}{l}\text { - Provision of services to foreign economic entities by importers/exporters of Ukraine, and provision of } \\
\text { the above-mentioned services by foreign economic entities to importers/exporters (subjects of FEA) } \\
\text { of Ukraine; }\end{array}$ & $\begin{array}{l}\text { Production, freight forwarding, insurance, consulting, } \\
\text { marketing, export, brokerage, agency, consignment, } \\
\text { management, accounting, audit, legal, tourist and etc. }\end{array}$ \\
\hline $\begin{array}{l}\text { - Scientific, scientific-technical, scientific-production, industrial, educational and other cooperation } \\
\text { with foreign subjects of economic activity; educational services and training of specialists on a } \\
\text { commercial basis; }\end{array}$ & Domestic and foreign higher education institutions \\
\hline $\begin{array}{l}\text { - International financial transactions and securities transactions in cases stipulated by the laws of } \\
\text { Ukraine; }\end{array}$ & $\begin{array}{l}\text { Brokers, dealers, traders, clearing companies, banks, } \\
\text { stock exchanges }\end{array}$ \\
\hline $\begin{array}{l}\text { - Credit and settlement transactions between domestic importers/exporters and foreign business } \\
\text { entities; } \\
\text { - Establishment of banking, credit and insurance institutions outside Ukraine by FEA entities } \\
\text { (importers/exporters) / foundation by foreign entities of the abovementioned institutions in the } \\
\text { territory of Ukraine in cases stipulated by the laws of Ukraine; }\end{array}$ & $\begin{array}{l}\text { International commercial (universal and specialized) } \\
\text { banks, interstate financial institutions. } \\
\text { Public authorities }\end{array}$ \\
\hline $\begin{array}{l}\text { Joint business activities between the subjects of foreign economic activity in Ukraine } \\
\text { (importers/exporters) and foreign business entities, including: } \\
\text { - creation of joint ventures of different types and forms, } \\
\text { - conducting joint business operations and } \\
\text { - joint ownership of property both on the territory of Ukraine and abroad; }\end{array}$ & $\begin{array}{l}\text { International tenders (open, closed), public } \\
\text { authorities; intermediaries depending on the type of } \\
\text { activity }\end{array}$ \\
\hline $\begin{array}{l}\text { - Entrepreneurial activity in the territory of Ukraine related to the granting of licenses, patents, know- } \\
\text { how, trademarks and other intangible property by foreign business entities; the similar activity of the } \\
\text { subjects of foreign economic activity outside Ukraine }\end{array}$ & $\begin{array}{l}\text { In the field of technology transfer: specialized } \\
\text { companies (innovative providers), spin-out and spin- } \\
\text { off companies }\end{array}$ \\
\hline $\begin{array}{l}\text { - Organization and implementation of activities in the field of exhibitions, auctions, auctions, } \\
\text { conferences, symposia, seminars, and other similar events carried out on a commercial basis, with the } \\
\text { participation of subjects of Foreign Economic Activity; }\end{array}$ & Agents attracting participants to exhibitions and fairs \\
\hline
\end{tabular}




\begin{tabular}{|l|l|}
\hline \multicolumn{1}{|c|}{ Types of FEA } & \multicolumn{1}{|c|}{ Intermediaries } \\
\hline $\begin{array}{l}\text { - Organization and implementation of wholesale, consignment and retail trade in the territory of } \\
\text { Ukraine in foreign currency in cases stipulated by the laws of Ukraine; }\end{array}$ & \\
\hline $\begin{array}{l}\text { - Commodity exchange (barter) operations and other activity based on forms of counter-trade between } \\
\text { the subjects of Foreign Economic Activity (domestic) and foreign business entities in foreign } \\
\text { currency in cases stipulated by the laws of Ukraine; }\end{array}$ & $\begin{array}{l}\text { Barter Exchanges (areas for an organized search for } \\
\text { goods or services, for barter transactions) }\end{array}$ \\
\hline $\begin{array}{l}\text { - Rental transactions, including leasing between the subjects of Foreign Economic Activity (domestic) } \\
\text { and foreign business entities; }\end{array}$ & $\begin{array}{l}- \text { When leasing involving three parties: } \\
- \text { Universal and specialized leasing companies; } \\
- \text { When financial leasing: } \\
\text { investors (shareholders, shareholders); } \\
\text { warehouse of a leasing company }\end{array}$ \\
& $\begin{array}{l}- \text { tenants looking for tenants; } \\
\text { Insurance Company; } \\
\text { bank; } \\
\text { a firm that repairs and renovates the leased and } \\
\text { returned facilities; }\end{array}$ \\
\hline $\begin{array}{l}\text { 15. Operations on the purchase, sale, and exchange of currency on foreign exchange auctions, currency } \\
\text { exchanges, and the interbank foreign exchange market; }\end{array}$ & $\begin{array}{l}\text { Foreign exchange auctions, currency exchanges, } \\
\text { banks }\end{array}$ \\
\hline $\begin{array}{l}\text { Works on the contractual basis of natural persons of Ukraine with foreign economic entities both within } \\
\text { the territory of Ukraine and abroad; work of foreign individuals on a contractually paid basis with } \\
\text { domestic FEA subjects both within the territory of Ukraine and abroad. }\end{array}$ & $\begin{array}{l}\text { Government agencies and private employment } \\
\end{array}$ \\
\hline
\end{tabular}

Source: [4-8, 13-15, 20-25, 28]. 
We agree with the point of view of T.S. Ruban, who divides resellers by volume of sales of one type of goods into wholesalers and retailers. Wholesale resellers are divided into: organized market institutes (exchanges, fairs, auctions, exhibitions, online platforms (e.g. alibaba.com), tender platforms (for example, prozorro.gov.ua); intermediaries to conduct trading operations (stock and commodity brokers; commercial consultants, experts, and analysts; agents; accidental intermediaries according to one of the typical ICC contracts)); and directly companies involved in commercial transactions (can be of different types, corresponding to certain activity models) [20].

Conclusion. Analysis of theoretical achievements in the field of study allowed covering to the maximum possible extent the classification criteria of intermediaries participating in International Business (FEA). By the criteria of online presence, it is proposed to allocate online, mixed and private intermediaries.

Online intermediaries are divided by size, level of state regulation, level of commercialization, degree of obligation, level of independence, branch affiliation, result visibility, services provided.

Mixed and physical intermediaries are classified according to systematic cooperation, customer specificity, territoriality, the direction of impact on the product, display of work, impact on the product, exclusivity. At the same time, the study of existing approaches allowed us to distinguish the classification criterion «by discrete types of principal and auxiliary activities» according to the theory of value chain of $\mathrm{M}$. Porter, according to which it is expedient to allocate intermediaries on the main (intralogistical, industrial, external logistic, marketing, trade, after-sales service) and ancillary activities (financial, information, legal, innovation, labor management, material, and technical supply).

The use of advanced classification will allow a more grounded and comprehensive approach to assess the impact of the use of intermediary structures on the efficiency of foreign economic activity of an enterprise and determine its level of competitiveness in the international market.

\section{REFERENCES}

1. Bereznyak, N.V. \& Kvasha, K.V. (2015). Rol poserednyts'kykh struktur v innovatsiynomu protsesi [The role of intermediate structures in the innovation process]. Naukovo-tekhnichna informatsiya - Scientific and Technical Information. №3, P. 25 [in Ukrainian].

2. Bereznyak, N.V. (2015) Dosvid funktsionuvannya spin-aut ta spin-off kompaniy dlya orhanizatsiyi analohichnykh poserednytskykh struktur $\mathrm{v}$ Ukrayini [Experience of functioning of spinouts and spin-off companies for the organization of 
similar intermediary structures in Ukraine]. Naukovo-tekhnichna informatsiya Scientific and Technical Information. № 4, P. 38 [in Ukrainian].

3. Duchynska, N.I. \& Sklema, H.V. (2017). Internet marketynh v Ukrayini [Internet Marketing in Ukraine]. Visnyk Dnipropetrovs'koho universytetu. Seriya «Ekonomika» - Bulletin of Dnipropetrovsk University. Series «Economy».Is. 11 (1), P. 89, Dnipro, Ukraine [in Ukrainian].

4. Dunska, A.R. (2012). Torhovi poserednyky v zovnishn'oekonomichniy diyal'nosti: problemy vyznachennya ta klasyfikatsiyi [Foreign trade intermediaries: problems of definition and classification]. Ekonomichnyy visnyk: zbirnyk naukovykh prats - Economic Bulletin: Collection of Scientific Papers, National Technical University of Ukraine «KPI». Is. 9, P. 89-95. Kyiv, Ukraine [in Ukrainian].

5. Dyma, O.O. (2015). Poserednyts'ka diyal'nist': transaktsiynyy pidkhid [Mediation: a transactional approach]. Visnyk sotsial'no-ekonomichnykh doslidzhen' Bulletin of socio-economic research, Vol. 1 (56). P. 49 [in Ukrainian].

6. Dyma, O.O. (2014). Analiz tendentsiy rozvytku poserednyts'kykh orhanizatsiy [Analysis of development trends of intermediary organizations]. Zovnishnya torhivlya: ekonomika, finansy, pravo - Foreign Trade: Economics, Finance, Law, 4 (75), P. 72 [in Ukrainian].

7. Dzyad, O.V. \& Tolstopyatykh, A.M. (2017). Rol' poserednykiv u pratsevlashtuvanni hromadyan ukrayiny za kordonom [The role of intermediaries in the employment of citizens of Ukraine abroad] PRYCHORNOMORS'KI EKONOMICHNI STUDIYI Naukovyy zhurnal - BLACK SEA ECONOMIC STUDIES Scientific Journal, Prychornomors'kyy Naukovo-Doslidnyy Instytut Ekonomiky ta Innovatsiy [The Black Sea Research Institute for Economics and Innovation],Is. 23, P.22. Odesa, Ukraine[in Ukrainian].

8. Honcharenko, O.O. (2017). Terminolohichne zabezpechennya teoriyi finansovoho poserednytstva: rozvytok klyuchovykh ponyat [Terminological Support for Financial Mediation Theory: Developing Key Concepts]. Oblik $i$ finansy Accounting and Finance. 1 (75)' 2017, P.132. [in Ukrainian].

9. International Chamber of Commerce (2010). ICC Guidelines on Agents, Intermediaries and Other Third Parties [Web edition]. Retrieved from: https://cdn.iccwbo.org/content/uploads/sites/3/2017/02/ICC-Guidelines-on-Agentsand-Third-parie(accessed at: June 2019).

10. International Chamber of Commerce (2015). Roles and responsibilities of intermediaries [Web edition]. Retrieved from: https://cdn.iccwbo.org/content/uploads/sites/3/2015/03/ICCBASCAP-Roles-and-Responsibilities-ofIntermediaries.pdf(accessed at: June 2019).

11. International Chamber of Commerce (2016). Intellectual property guidelines for business [Web edition]. Retrieved from: https://cdn.iccwbo.org/content/uploads/sites/3/2016/11/IP-guidelines-for-business-English.pdf.-c.8(accessed at: June 2019). 
12. International Chamber of Commerce (2017). 2017-2018 Programme of action [Web edition]. Retrieved from: https://cdn.iccwbo.org/content/uploads/ sites/3/2017/03/ICC-programme-of-action-2017-2018.pdf - P.14.(accessed at: June 2019).

13. Kibik, O.M. \& Khayminova, Yu.V. (2017). Zasady rozvytku uchasti mytnykh ta inshykh poserednykiv u realizatsiyi eksportnoyi stratehiyi Ukrayiny [Principles of development of participation of customs and other intermediaries in the implementation of Ukraine's export strategy]. Rozvytok metodiv upravlinnya ta hospodaryuvannya na transporti - Development of methods of management and management in transport, Collection of Scientific Papers of Odesa National marine UniversityNo. 4 (61). P. 16 [in Ukrainian].

14. Kudryavska, N.V. (2018). Sutnist' i klasyfikatsiya strakhovoho poserednytstva: yevropeys'kyy ta ukrayins'kyy dosvid [The essence and classification of insurance mediation: European and Ukrainian experience]. Visnyk Zhytomyrs'koho derzhavnoho tekhnolohichnoho universytetu - Journal of Zhytomyr State Technological University. 2 (84), P.125 [in Ukrainian].

15. Kvach, YA. P., Borisov, O.H. \& Lopatko K.M. (2014). Vydy poserednykiv u zovnishnoekonomichniy diyalnosti: teoretychni aspekty [Types of intermediaries in foreign economic activity: theoretical aspects]. Zovnishnya torhivlya: ekonomika finansy y pravo - Foreign Trade: Economics of Finance and Law. 1(72), P. 34 [in Ukrainian].

16. Kysylova, E.N. (2014). Orhanizatsiya komertsiynoyi diyal'nosti po haluzyakh ta sferakh zastosuvannya [Organization of business by industry and scope].Kondor [publishing house], Kyiv, Ukraine - 292 p. [in Ukrainian].

17. Pavlishyna, N. M. (2015). Poserednyky u merezhi internet [Intermediaries in the Internet]. Derzhava ta rehiony Seriya: Ekonomika ta pidpryyemnytstvo - State and Regions Series: Economics and Entrepreneurship, 1(82), P. 102 [in Ukrainian].

18. Ruban, T.S. (2017). Evolyutsiya instytutu poserednytstva $\mathrm{V}$ svitoviy ekonomitsi [Evolution of the Mediation Institute in the World Economy]. Ekonomichnyy visnyk Zaporiz'koyi derzhavnoyi inzhenernoyi akademiyi - Economic Bulletin of Zaporizhzhya State Engineering Academy. Vol. 5 (11), P.41 [in Ukrainian].

19. Ruban, T.S. (2017). Suchasni traktuvannya poserednytstva $v$ svitoviy ekonomitsi [Modern interpretations of mediation in the world economy]. Hlobalni ta natsionalni problemy ekonomiky - Global and national economic issues. Elektronne naukove fakhove vydannya, Mykolayivs'kyy natsional'nyy universytet imeni V.O. Sukhomlyns'koho [Electronic Scientific Professional Edition, V.O. Sukhomlinsky Mykolaiv National University], Is. 17, P. 86 [in Ukrainian].

20. Ruban, T.S. (2018). Diversification of mediation models in the global food market. International Journal of Innovative Technologies in Economy. №1(13), P.11. 
21. Samoylovska, V.P. \& Korobkova, O.M. (2015). Ekonomichna sutnist mytnoho poserednytstva [Economic essence of customs mediation]. Innovatsiyna ekonomika - Innovative economy. №4, P. 259 [in Ukrainian].

22. Sholoyko, A. (2017). Yevropeyskyy vektor rozvytku diyalnosti nestrakhovykh poserednykiv v Ukrayini [European vector of non-insurance mediators' activity development in Ukraine]. Visnyk Kyyivskoho natsionalnoho universytetu imeni Tarasa Shevchenka. EKONOMIKA - Newsletter of the Taras Shevchenko National University of Kyiv.ECONOMY. 5(194), p. 66 [in Ukrainian].

23. Shvaydak, A.M. (2017). Formuvannya suspilnoho potentsialu nebankivskykh finansovykh poserednykiv ta yikh konsolidatsiya na rynku [Non-bank financial intermediaries building social capacity and consolidation in the market]. Visnyk Odeskoho natsionalnoho Universytetu imeni I.I.Mechnikova - Bulletin of the Odessa I.I. Mechnikov National University. 12 (65), P. 242 [in Ukrainian].

24. Svichkar, V.A. (2018). Komertsiyna diyalnist poserednytskykh kompaniy v umovakh rynkovoyi ekonomiky [Intermediary commercial activities in a market economy]. Ekonomika i rehion - The economy and the region. № 1(68), P.149 [in Ukrainian].

25. Tkachenko, T.I. (2016). Vystavkovyy biznes [Exhibition business]. Monograph by T.I. Tkachenko, T.P. Duplyak (ed.). - Kyiv National Trade and Economics University, 244 p. [in Ukrainian].

26. Velychko, K.Yu. \& Nosach, L.L., Pechenka O.I. (2017). Suchasni tendentsiyi ta perspektyvy rozvytku rynku internet-torhivli: mizhnarodnyy dosvid ta natsional'na praktyka [Current trends and prospects for the development of the Internet commerce market: international experience and national practice]. Ekonomichna stratehiya i perspektyvy rozvytku sfery torhivli ta posluh -Economic Strategy and Prospects for Trade and Services Development: Collection of Scientific Papers. Kharkiv, Ukraine. Is. 1 (25), P. 184-196. Retrieved from: http://nbuv.gov.ua/UJRN/ esprstp_2017_1_20 [in Ukrainian].

27. Zakon Ukrayiny «Pro zaynyatist' naselennya» № 5067-17 vid 5 lypnya 2012r. [The Law of Ukraine «On Employment» No. 5067-17 of July 5, 2012]. (n.d.) zakon.rada.gov.ua. Retrieved from: http://zakon2.rada.gov.ua/ laws/show/-5067-17 (accessed at: June 2019) [in Ukrainian].

28. Zakon Ukrayiny «Pro zovnishnoekonomichnu diyalnist» № 959-XII 16.04.1991 [Law of Ukraine «On Foreign Economic Activity» № 959-XII dated 16.04.1991]. (n.d.) zakon.rada.gov.ua. Retrieved from: https://zakon.rada.gov.ua/ laws/show/959-12 